\title{
Archiving the Postcolonial City
}

by

\author{
Ferdinand de Jong \& David Murphy
}

\begin{abstract}
The city, however, does not tell its past, but contains it like the lines of a hand, written in the corners of the streets, the gratings of the windows, the banisters of the steps, the antennae of the lightning rods, the poles of the flags, every segment marked in turn with scratches, indentations, scrolls.
\end{abstract}

Italo Calvino, Invisible Cities $^{1}$

The archive has emerged as a critical tool to conceptualize the heuristic value of history, heritage and memory in debates on postcolonial futures. In this special issue, we take stock of the possibilities for the colonial and postcolonial archive to provide frameworks for the imagination of postcolonial futures. ${ }^{2}$ We posit that archival work in the postcolonial city may help retrace the past in order to reconfigure the future. In the current climate of postcolonial malaise, the archival imagination may constitute a significant component in the reconfiguration of postcolonial futures. However, such claims can only be made if we are indeed allowed to imagine the city as an archive, to be read in an archival way. How can such a concept of the city be defended?

The archive, as an institution, has been defined as an organized body of documents produced by an institution with the aim of preserving them. ${ }^{3}$ If we stick to this conventional definition of the archive, then the city, subject to multiple authorities and constant contestations, cannot be conceived as an archive in the conventional sense. To argue that the city can be seen as an archive, we need to acknowledge what Paul Ricoeur has identified as an important paradox of the archive, which pertains to the status of the 'document' as an authorized deposit. If documents have always constituted the evidence used by historians to authorize their stories, their status as evidence has recently become suspect. This is so because the document shares with the monument an obvious finality: to commemorate what its contemporaries deemed worthwhile committing to memory. Documents have been exposed as 'monuments', with intentional

\footnotetext{
${ }^{1}$ Italo Calvino, Invisible Cities (London: Vintage, 1997), p. 11. Originally published as Le cita invisibili (1972).

${ }^{2}$ All articles in this special issue on Archiving the Postcolonial City were initially presented in one of three workshops organized as part of the AHRC Research Network on Utopian Archives: Excavating Pasts for Postcolonial Futures. We would like to thank the AHRC profusely for the funding that has enabled us to organise these workshops, and Paul Basu (UCL) for his role as Co-Investigator and host of one of the workshops. We would also like to thank the participants in these workshops whose papers do not appear here (but will elsewhere), for their contributions to the debates that have fed into this special issue.

${ }^{3}$ Paul Ricoeur, Time and Narrative, Vol. 3, translated by Kathleen Blamey and David Pellauer (Chicago and London: The University of Chicago Press, 1988), p. 116.
} 
pedagogic purposes to instruct their progeny. This has led Ricoeur to observe that 'the most valuable traces are the ones that were not intended for our information'. ${ }^{4}$ As contemporaries never 'documented' what they did not consider worth remembering, historians have developed an interest in documents that lack the authority of the archive. This paradox suggests that as a deposit of unintended 'documents', the city may be seen as a non-institutional archive in which 'evidence' is found in the traces of events that went unrecorded. Such an anti-institutional reading of evidence has recently gained prominence in the tracing of traumatic histories that can only be known through 'spectral' evidence, which consists of those impressions that may be traces of trauma, but for lack of historical indexicality cannot be authorized as 'documents'. ${ }^{5}$ Such spectral evidence needs to be prospected in the subterranean histories of postcolonial cities to access the trauma of colonialism.

That the archive is not the place to look for 'impressions' of hidden histories was also suggested by Derrida who identified the archive as always working, and a priori, against itself ${ }^{6}$ Reflecting on the death drive that Freud identified as a drive for destruction, Derrida posits that the institution of the archive produces amnesia. Leaving no traces, the death drive even erases the evidence of its own destructions. Paradoxically, says Derrida, 'the archive takes place at the place of originary, structural breakdown of memory, introducing forgetfulness into the heart of the 'monument' . ${ }^{7}$ Real memory, Derrida argues, is situated outside the archive. Leaving the archive, then, we need to look for traces in the street, the gutter, the hidden alleys, all those spaces never intended to commemorate, but on which history has nevertheless made its 'impressions'.

It is certainly in that sense that Victor Hugo's Les Misérables should be read. For Hugo, Paris is a place of 'innumerable pockets and recesses' that are the 'product of infinite poverty and deprivation'. ${ }^{8}$ It is through these spaces that we get to know the lives lived beyond the city lights in the spaces hidden by Haussmann's boulevards. Indeed, if the city is an archive it is 'a very messy kind of archive' (Rao 2009: 371), an archive whose 'documents' remain hidden from plain sight. To access this archive is not an easy task. Although there may be no archons to regulate entry into the city's archive, an 'archival' sensibility is required to see what constitutes a monument, a document, a trace. Seeing a potential order in this archive renders the city as a Utopia, an order that we know

\footnotetext{
${ }^{4}$ Ricoeur, p. 117.

${ }^{5}$ Ulrich Baer, Spectral Evidence: The Photography of Trauma (Cambridge, MA, \& London: The MIT Press, 2002).

${ }^{6}$ Jacques Derrida, Archive Fever: A Freudian Impression, trans. by Eric Prenowitz (Chicago: Chicago University Press, 1996).

${ }^{7}$ Derrida, p. 12.

${ }^{8}$ Michael Sheringham, 'Archiving', in Matthew Beaumont and Gregory Dart (eds), Restless Cities (London: Verso, 2010), pp.1-17.
} 
cannot be realised. ${ }^{9}$ The city cannot be objectified as archive, but may be traversed 'archivally'.

Over the past decade, the field of French Studies (with Sheringham at the forefront) has explored the ways in which recent French novelists have sought through their writing to uncover the hidden archives of the city, the traces of the past to be found in the material fabric of the urban landscape. The work of Patrick Modiano and Georges Perec has been particularly influential in this context. In novels such as Perec's $W$ ou le souvenir d'enfance or Modiano's Dora Bruder, the traces of the past are uncovered in a complex, fragmented and necessarily incomplete fashion. ${ }^{10}$ In these instances, the past to be uncovered is that of France's Jewish population, forced into hiding or deported during the Second World War: their trace seemingly erased from the city, they become visible once again under the watchful eye of the novelist. Although the Holocaust has understandably occupied a privileged position, tracing the colonial past of the city has been a recurring feature of the novels of authors such as Leilla Sebbar in La Seine était rouge, which uncovers the massacre of peaceful Algerian demonstrators by the Paris police on the night of 17 October 1961, in the so-called Bataille de Paris. ${ }^{11}$ The same event is explored in Didier Daeninckx's polar, Meurtres pour mémoire but this time the city as palimpsest reveals the Holocaust beneath the traces of 17 October 1961 in a fictionalized version of Maurice Papon, chief of Police in Paris on that fateful night, and Vichy official responsible for the deportation of the Jews in the Bordeaux area during the war. ${ }^{12}$ In this special issue, the contributors extend the examination of urban archives beyond this literary exploration of such questions in order to engage with a wider range of social, cultural and political practices that seek to mobilize the city as archive.

As sites of history, cities are privileged places for the deposit of historical traces. For this reason, cities have been studied as palimpsests, parchment scrolls saturated with layers and layers of texts inscribed over centuries, but never entirely erased from their textures. The very materiality of the city can be accessed through methods usually associated with archaeology. Thus one is compelled to excavate the strata of deposits, but typically for the palimpsest such strata have intermingled to the extent that past and present are hard to disentangle. In his book on urban palimpsests Huyssen has provided us with an archaeology of the voids of Berlin. ${ }^{13}$ As these voids were filled with new developments after the city's reunification, older layers of the city's history were reduced to traces, almost rendering the city as tabula rasa, but not quite. To see the city as palimpsest enables one to account for the past in the present. Moreover, it enables

\footnotetext{
${ }^{9}$ Louis Marin, 'Frontiers of Utopia: Past and Present', Critical Inquiry, 19 (1993), 397-420 (p. 412).

${ }^{10}$ Georges Perec, W ou le souvenir d'enfance (Paris: Denoël, 1975); Patrick Modiano, Dora Bruder (Paris: Gallimard, 1997).

${ }^{11}$ Leilla Sebbar, La Seine était rouge: Paris, octobre 1961 (Paris: Thierry Magnier, 1999).

${ }^{12}$ Didier Daeininckx, Meurtres pour mémoire (Paris: Gallimard, 1984).

${ }^{13}$ Andreas Huyssen, Present Pasts: Urban Palimpsests and the Politics of Memory (Stanford: Stanford University Press, 2003).
} 
one to acknowledge the co-existence of different 'regimes of memory' and their accumulating production of different temporalities in the present. ${ }^{14}$

In this special issue, we are looking at how the colonial past has been 'archived' in documents, monuments and unintended traces in the postcolonial city. To give an account of this archive requires a sensitivity to the historicity of the city. Some have observed that such accounts necessarily involve time-travelling between past and present. In Austerlitz, W.G. Sebald takes us on a journey through time, travelling between epochs and empires, guided by the monuments of the imperial cities his protagonists visits. In Sheringham's reading of this travelogue of time, cities appear as repositories of written traces that are visited and revisited by the protagonists as they meet each other in a twilight zone between present and past. Recounting the construction of innumerable monuments, the travelogue sets these monuments in motion, 'through connections that are deeply rooted in historical realities but also serve to dissolve time'. ${ }^{15}$

If the city-as-archive facilitates time-travelling, we should also acknowledge that the tracing and re-tracing of the past is inevitably bound up with visions of the future. Cities have always been places of the imagination, especially of the future. An expansive range of science fiction has imagined the city as a dystopic space and such dystopian imaginaries are now increasingly projected on the postcolonial city. ${ }^{16}$ It is not selfevident how the postcolonial city should be defined, as cities in the Global South seem to range very widely along different spectrums. But in terms of their historicity, the cities that we address do not resemble the Generic Cities that Koolhaas identified as those urban forms in China's Pearl River Delta that have arisen out of nothing, places without history. ${ }^{17}$ In contrast, the cities analysed here are all saturated with history and weighed down with the burden of the (colonial) past.

It is that past that constitutes their archival value, the raw material waiting to be translated into a possible future. Indeed, the question central to six articles collected here is how the past, accessed through the archive, can speak to the future. One of the interesting questions in archival research is to what extent past events leave 'traces' in documents. How can pasts be traced? The quality of the trace to signify the past in the present questions the epistemology of history based as it is on the assumption of the existence of linear time. Traces are temporally ambiguous: They are both the absence of a presence and the presence of an absence. The trace shares this quality with Utopia,

\footnotetext{
${ }^{14}$ Paul Basu, 'Palimpsest Memoryscapes: Materializing and Mediating War and Peace in Sierra Leone', in Ferdinand de Jong and Michael Rowlands (eds), Reclaiming Heritage: Alternative Technologies of Memory in West Africa (Walnut Creek: Left Coast Press, 2007), pp. 231-59.

${ }^{15}$ Sheringham, p. 9.

${ }^{16}$ Gyan Prakash, Noir Urbanisms: Dystopic Images of the Modern City (Princeton and Oxford: Princeton University Press, 2010).

17 O.M.A., Rem Koolhaas and Bruce Mau, S,M,L,XL (New York: The Monacelli Press, 1995), pp. 1328-64.
} 
which is 'philosophically analogous to the trace, only from the other end of time' ${ }^{18}$ Like the trace, which belongs both to the past and the present, Utopia belongs both to the present and the future. If the archive is a technology for the storage of traces of the past, can we then also imagine the archive as a technology for the storage of futures? In this special issue, we explore whether the city can be a space for the imagination of postcolonial futures. Accepting Rao's critique that the archive should not be conceptualized as a repository for 'stable forms', we like to think of the 'city-as-archive as a tool, refashioning our relation to the future'19.

The presentation of the essays in two sets is ordered by the temporality of the archive. Kate Marsh reads the decrepit materiality of Pondichéry's cityscape as an archive of imperialism. She demonstrates how French commentators have interpreted the city's fragile monumentality as evidence of a French empire that never was, but could have been. Throughout the era of declining French influence in India, contemporaries read the traces of the colonial cityscape as a screen to hide their impotence and imagine a power they never had. Following on from Marsh's article on this outpost of the French empire in India, De Jong's article focuses on Senegal, exploring Saint-Louis's cityscape, the conservation of which is motivated by colonial nostalgia. Although the monuments of French colonialism facilitate such nostalgia, the cityscape also provides the focus for an annual commemoration of anti-colonial resistance. As De Jong demonstrates, the disciples of a Sufi Saint have recuperated the traces of his anti-colonial resistance and preserve them in what might be termed a counter-archive. Such counter-archives are also found in the shantytowns of Algiers and Casablanca. Searching for traces of the violence committed in the name of (anti-)colonialism, Jim House demonstrates that its memory is not preserved in the city's centre, but in the peripheral shantytowns that harbour their own archives of the nationalist struggle. House examines these shantytowns as depositories of memories remembered in political struggles between the local and the national. If shantytowns can indeed be seen as counter-archives, House's contribution convincingly demonstrates that their reading is far from consensual, but subject to different party political lines. These three articles analyse how contemporary observers read historical cityscapes and engage with the partisan memory work in which colonialism is at stake. The debris of the colonial city, its monuments to empire builders, its police cells and detention centres constitute the 'documents' of the archive consulted by its readers.

In contrast, the second set of three articles focuses on contemporary interventions in postcolonial cityscapes in order to commemorate and 'consign' new documents to the archive. Bruno Levasseur documents the production of a cd with songs about life in the Parisian banlieue of La Courneuve. Subtly registering how these songs take their cue from daily life in a multicultural suburb and how they present a different take on the French debate on national identity, Levasseur demonstrates how the suburb presents

${ }^{18}$ Fredric Jameson, Archaeologies of the Future: The Desire Called Utopia and Other Science Fictions (London and New York: Verso, 2005), p. xv, footnote 12.

${ }_{19}$ Vyjayanthi Rao, 'Embracing Urbanism: The City as Archive', New Literary History, 40 (2009), 371-81. 
its own vision of a future of cultural hybridity in France. Of a very different nature is Charles Forsdick's analysis of the debates surrounding memory, monuments and the archive. Taking stock of this debate in the Caribbean (and beyond), Forsdick presents a comprehensive overview on the potential of the archive to contribute to the commemoration of slavery and the slave trade. Focussing on the establishment of the Mémorial de l'abolition de l'esclavage in Nantes, he suggest that this monument realises in a different form Édouard Glissant's un-realised vision for a new archival space for the commemoration of slavery. Whilst Forsdick's essay suggests that new archival practices may create spaces for commemoration, Claire Launchbury's article establishes that archival practices in Beirut can only hint at the city's incapacity to remember. In the uneasy peace that has followed the Civil War, the destruction of the past is everywhere visible but not publically acknowledged: the national government cannot authorize a national archive for fear of releasing the ghosts of the past, and in this vacuum, the city's elite celebrates a consumer culture that seeks to gloss over the past. In the absence of archives, Launchbury describes two surrogate archives produced by Beirut's artists, interventions in the oblivious cityscape that invite the passer-by to remember.

In sum, the first three articles focus on the material deposits of the palimpsest city and trace what might have happened on the basis of the traces that constitute an uninstitutional archive. In contrast, the final three articles presented here focus precisely on the production of such 'documents' and 'monuments' after the fact in order to institute an archive. In these papers we are invited to witness how monuments are created to counter forgetting and preserve the memory of what has happened. The first three articles read historical traces as testimonies of colonialism; the final three scrutinize the production of documents in the present. The historical indexicality of the documents in these archives differs but remains uncontested. In the last article, such historical indexicality is presented as problematic and even proclaims its own impossibility.

Adopting a postcolonial stance in the programmatic first issue of this journal, Lydie Moudileno followed Chakrabarty's suggestion to provincialize Europe, by looking at literary productions in France's provinces and its territoires outremer. ${ }^{20}$ In this special issue, we are effectively following her lead by looking at postcolonial cities in France's former colonies (Pondichéry, Algiers, Casablanca, Saint-Louis and Beirut), in France's provinces (Nantes) and the Parisian banlieue (la Courneuve). This selection of sites conveys how colonialism is 'archived' in decentred francospheres. The de-centring that we pursue here should enable new ways of thinking about the city as postcolonial archive and its potential to contribute to postcolonial imaginaries. To be clear, there are some potential adverse effects to this exercise. In his scathing review of the reception of postcolonial studies in France (or, the absence of it), Achille Mbembe implies that there is no need to provincialize France. ${ }^{21}$ From his assessment of French academic

\footnotetext{
20 Lydie Moudileno, 'The postcolonial provinces', Francosphères 1.1 (2012), 53-68.

${ }^{21}$ Achille Mbembe, 'Provincializing France?', trans. by Janet Roitman, Public Culture, 23.1 (2011), 85-119.
} 
approaches to postcolonialism, it become abundantly clear that academic Paris is itself already utterly provincial. One of the consequences of France's Parisianism is that France's memory of colonialism has remained repressed for a very long time. With recent openings in the debate on the colonial legacy, it has now become possible to trace colonial pasts in francophone cities. But by concentrating on peripheral cities, the risk is that the legacy of colonialism in Paris remains 'un-archived'. Others have already observed how provincializing the archive might not de-centre, but rather reinforce the centre. $^{22}$ Our initiative to provincialize the archive should not prevent others from searching the archive of the Seine.

22 Matthew Kurtz, 'A Postcolonial Archive? On the Paradox of Practice in a Northwest Alaska Project', Archivaria: The Journal of the Association of Canadian Archivists, 61 (2007), 63-90 (p.67). 